\title{
İlköğretim Akademik Başarı Ölçüleri İle Temel Eğitimden Ortaöğretime Geçiş Sınav Puanları Arasındaki İlişki ${ }^{1}$
}

Gürkan Karakoç²

\section{İbrahim Alper Köse ${ }^{3}$}

\section{Type/Tür:}

Research Article/Araştırma Makalesi

Received/Geliş Tarihi: February 9/9 Şubat 2018

Accepted/Kabul Tarihi: June 7/7

Haziran 2018

Page numbers/Sayfa No: 121-142

Corresponding Author/İletişimden Sorumlu Yazar:

grknkrkc@gmail.com

\section{$\checkmark$ iThenticate ${ }^{\circ}$}

This paper was checked for plagiarism using iThenticate during the preview process and before publication. / Bu çalışma ön inceleme sürecinde ve yayımlanmadan önce iThenticate yazılımı ile taranmıştır.

Copyright $@ 2018$ by Cumhuriyet University, Faculty of Education. All rights reserved.

\section{Öz}

$\mathrm{Bu}$ araştırma ile Temel Eğitimden Ortaöğretime Geçiş (TEOG) sınavına giren öğrencilerin TEOG sınavı alt testi ham puanları ile ortaokuldaki ilgili derslere ait ders başarı ölçüleri arasındaki ilişkiler tespit edilmeye çalışılmıştır. Araştırma kapsamında, öğrencilerin 6. ve 7. sınıf matematik, Türkçe, din kültürü ve ahlak bilgisi, fen bilimleri, sosyal bilgiler ve İngilizce derslerine ait başarı ölçülerinin TEOG sınavı alt testi ham puanlarını yordama düzeyi belirlenmeye çalışılmıştır. Araştırma kapsamında öğrencilerin 6. ve 7. sınıf matematik, Türkçe, din kültürü ve ahlak bilgisi, fen bilimleri, sosyal bilgiler ve İngilizce dersi yazılı sınav, ders etkinliklerine katılım ve performans görevi puanları bağımsız değişken; TEOG sınavı matematik, Türkçe, din kültürü ve ahlak bilgisi, fen bilimleri, sosyal bilgiler ve İngilizce alt testi ham puanları ayrı ayrı bağımlı değişken olarak ele alınmıştır. Bağımlı değişken ile bağımsız değişkenler arasındaki ilişki çoklu regresyon analizi ile incelenmiştir. Araştırma sonucunda TEOG sınavı matematik, Türkçe, din kültürü ve ahlak bilgisi, fen bilimleri ve sosyal bilgiler alt testi başarısını en yüksek düzeyde yordayan değişkenin ilgili derslere ait başarı ölçülerinden yazlı sınav değişkeni olduğu; TEOG sınavı İngilizce alt testi başarısını en yüksek düzeyde yordayan değişkenin ders etkinliklerine katılım değişkeni olduğu; performans görevi değişkeninin TEOG sınavi sosyal bilgiler ve İngilizce dersi başarılarının açıklarken matematik, Türkçe, din kültürü ve ahlak bilgisi, fen bilimleri başarısını açıklamada yetersiz kaldığı görülmüştür.

Anahtar Kelimeler: Regresyon analizi, güvenirlik, geçerlilik, TEOG sınavı, akademik başarı

\section{Suggested APA Citation/Önerilen APA Atıf Biçimi:}

Karakoç, G. ve Kösel, İ. A. (2018). İlköğretim akademik başarı ölçüleri ile temel eğitimden ortaöğretime geçiş sınav puanları arasındaki ilişki. Cumhuriyet International Journal of Education, 7(2), 121-142 http://dx.doi.org/10.30703/cije.392386

\footnotetext{
${ }^{1}$ Bu makale yazarın "İlköğretim Akademik Başarı Ölçüleri İle Temel Eğitimden Ortaöğretime Geçiş Sınav Puanları Arasındaki İlişki" adlı yüksek lisans tezinden alıntıdır.

2 Bilim Uzmanı, Milli Eğitim Bakanlığı, Bolu/Turkey

Master of science, Ministry of National Education, Bolu/Türkiye

e-mail: grknkrkc@gmail.com

ORCID ID: $\underline{\text { http: / / orcid.org/0000-0002-1760-6098 }}$

${ }^{3}$ Doç. Dr., Abant İzzet Baysal, Eğitim Fakültesi, Eğitim Bilimleri Bölümü, Bolu/Türkiye

Assoc. Prof., Abant İzzet Baysal University, Faculty of Education, Department of Education Sciences, Bolu/Turkey e-mail: i.alper.kose@gmail.com

ORCID ID: http:// orcid.org/0000-0003-0842-1929
} 


\title{
The Relationship Between Elementary School Academic Achievement Levels and High School Entrance Exam Scores
}

\begin{abstract}
This study investigated the relationship between secondary school entrance exam scores (TEOG) and students' academic achievement during their elementary school years. Main goal of the study was to examine how well grade 6 and 7 mathematics, Turkish, education of religion and ethics, science, social sciences and English scores predict TEOG exam scores. Grade 6 and 7 mathematics, Turkish, ethics, science, social sciences and English written exam scores, participation levels in classroom activities and performance grades were independent variables. Mathematics, Turkish, education of religion and ethics, science, social sciences and English scores in TEOG exams were dependent variables of the study. Multiple regression analysis was used to investigate the relationship between dependent and independent variables. Grade 6 and 7 written exam scores were better predictor of TEOG exam scores in mathematics, Turkish, education of religion and ethics, science, social sciences when compared to other independent variables. On the other hand, participation levels to classroom activities were better predictor of TEOG English exam scores when compared to other independent variables. Additionally, while performance task scores is a predictor of TEOG scores in social sciences and English, it is not a predictor of mathematics, Turkish, education of religion and ethics, and sciences.
\end{abstract}

Keywords: Regression Analysis, Validity, Reliability, TEOG Exam, Academic Success

\section{Giriş}

Eğitim ile ilgili yapılan tanımlara bakıldığında, eğitimin birçok eğitimci tarafından değişik biçimlerde tanımlandığı görülmektedir. Fidan (1986), bireyi belirli amaçlar doğrultusunda yetiştirme süreci olarak tanımlarken; Demirel (2004) eğitimi, belirli bir plan ve program doğrultusunda bireylerde kendi yaşantısı ve kültürlenme yolu ile davranış değişikliği oluşturma süreci olarak tanımlamaktadır.

Yukarıdaki tanımlar incelendiğinde, eğitimin gerçekleşmesi için önceden belirlenmiş amaçların olması gerektiği, bireyde davranış değişikliğinin meydana geleceği ve bu değişikliğinin yaşantılar yoluyla oluşacağı anlaşılmaktadır. Eğitim, hayat boyu devam eden davranış değiştirme süreci olarak ele alınıp analiz edildiğinde en belirgin özellikleri şöyledir: her zaman ve mekânda gerçekleşebilmesi, süreklilik arz etmesi ve çok yönlü olması, bilgi dahil her türlü yaşantı ile gerçekleşmesi ve bu yaşantıların tesadüfi olması veya olmamasıdır (Varış, 1978).

Günümüzde eğitim, davranış geliştiren bir sistem olarak ele alınmaktadır. Diğer bütün sistemlerin yapısında olduğu gibi bu sistemde de girdiler, süreç, kontrol ve çıktılar vardır. Girdiler, sistemin hedeflerine ulaşabilmesi için, dışarıdan yollanan tüm değişkenleri ifade etmektedir. Süreç, eğitim programı ile öğrenciye kazandırılması hedeflenen davranışların, işlevsel hale dönüştürüldüğü etkinlikleri kapsamaktadır. Çıktı ise, öğrencinin eğitim programı sonundaki durumudur. Sistemin hedeflerinin ne derece gerçekleştiğini ortaya koymak üzere yapılan tüm etkinlikleri kapsar. Bu sistem sonunda öğrenci istendik davranışı kazanmış veya kazanmamış olabilir. Bu durum ise eğitimde sonuçların ne derece gerçekleştĭgini belirlemek için eğitimin dördüncü öğesi olan kontrol öğesini meydana getirir. Böylece öğrencinin istenilen davranışı kazanıp kazanmadığı kontrol edilir. Sistem 
kontrol öğesi sayesinde kendini yeniler. Böylece değiştirilmesi gereken ve uyumsuz olan noktalar belirlenir (Baykul, 1992; Baykul, 2010; Sönmez, 2012).

Her sistemde olduğu gibi eğitiminde kontrol öğesi ölçme ve değerlendirmeden oluşmaktadır. Ölçme ve değerlendirme, birbirleriyle bağıntılı ve aynı zamanda birbirlerini tamamlayan öğelerdir. Uygulanan bir eğitimin istenilen hedeflere ulaşıp ulaşmadığının, ulaşıldı ise bunun derecesinin; aynı zamanda okullarda uygulanan eğitimin istenilen nitelikte olup olmadığının belirlenmesi gerekir. Bunun belirlenmesi öğrencide meydana gelen gözlenebilir ve ölçülebilir davranışların ölçülüp değerlendirmesi ile mümkündür. Eğitim sisteminde ölçme ve değerlendirme, bu sürecin önemli bir parçası olmakla beraber nitelik artırma çalışmalarının önemli bir öğesidir (Baykul, 2010; Turgut, 1984).

Turgut (1984) ölçmeyi, bir niteliğin gözlem sonuçlarına dayanarak sayılarla ya da sembollerle ifade edilmesi; Tekin (2010), bir nesne ya da nesne grubunun belirli bir özelliğe sahip oluş derecesinin gözlem sonuçlarından hareketle sembollerle ilişkilendirilmesi; Arıcı (1997), bir objenin, durumun ya da bireyin belirlenen bir niteliğe sahip oluş derecesine belli kurallara göre sembolik değerler verme işi olarak tanımlamıştır. Bu tanımlara bakıldığında ölçme işinde gözlenecek bir nitelik ve bu niteliğe belirli kurallara göre sayılar verme durumları görülür (Tekindal, 2012).

Değerlendirmeyi bir yargılama işi olarak ele alan Tekin (2010), değerlendirmeyi iki şeyin karşılaştırılmasına dayandırır ve ölçme sonuçlarından anlam çıkarmak için ölçülen özellik hakkında bir yargıya varmak olarak tanımlar. Turgut (1984) değerlendirmeyi, ölçme sonuçlarını bir ölçütle kıyaslayarak karara varmak şeklinde tanımlamaktadır. Değerlendirmenin bu tanımında üç öğe karşımıza çıkmaktadır. Bunlar: ölçme sonuçları, ölçüt ve karardır. Bunlardan ölçme, verilecek karara esas olacak bilginin toplanması işidir. Kararların isabetlilik derecesi, ölçütün uygunluğunun yanında ölçme sonuçlarının geçerlik ve güvenirliğine bağlıdır (Baykul, 2010).

Güvenirlik ölçme aracının sahip olması gereken temel niteliklerden biridir. Güvenirlik, aynı bireylerden elde edilen, bir niteliğe ait ölçümlerin benzer veya aynı koşullarda tekrar edilebilirliği şeklinde tanımlanır (Crocker ve Algina, 1986). Ölçme sonuçlarında tesadüfi hatalar ne kadar az ise ölçme sonuçları o oranda güvenilirdir.

Geçerlik, ölçme aracının ölçmeye çalıştı̆̆ı niteliği başka özelliklerle karıştırmadan doğru olarak ölçebilmesidir, yani ölçme aracının amacına hizmet etme derecesidir (Tekin, 2010). Aslında geçerliğin tek bir tanımını yapmak ya da geçerliği tek bir katsayı olarak nitelendirmek oldukça güçtür. Bunun yerine geçerlik için testin kullanım amacına uygun kanıtlar ortaya koymak demek daha doğru olur. Durum böyle olunca tek bir geçerlikten değil, geçerlik türlerinden söz etmek gerekir (Baykul, 2010; Kan, 2009). Eğitimde kullanılan geçerlik türleri şöyledir: Yap1 geçerliği, kapsam geçerliği, görünüş geçerliği ve ölçüt dayanaklı geçerliktir (Anastasi, 1988).

1. Yapı geçerliği: Ölçme aracının geliştirilme amacına hizmet etme derecesidir. Yani ölçme aracının o araç ile ölçülmeye çalışılan yapıyı ortaya koyabilme derecesidir (Anastasi, 1988; Erkuş, 2003). Yapı, birbirleriyle ilintili olduğu öngörülen öğe ya da bu öğeler arasındaki ilişkilerden oluşan bir örüntüdür. Yapı geçerliği bu bağlamda ele alındığında test maddelerine verilen cevaplar ve bu cevaplar arasındaki ilişkilerin analiz edilmesi sürecidir (Tekin, 2010). 
2. Kapsam geçerliği: Bir testin ve testte yer alan her bir maddenin bu testle ölçülmeye çalışılan davranışları ne derece kapsadığını ifade eder (Baykul, 2010). Ölçmeye konu olan davranışı yeterli ve dengeli olarak kapsayan ve kapsadığı her madde ile ölçülmek istenen davranışı doğrudan ölçen test, kapsam geçerliğine sahiptir (Tekin, 2010).

3. Görünüş geçerliği: Teknik anlamda bir geçerlik türünü ifade etmemekle birlikte, bir testin neyi ölçtüğünü değil, neyi ölçüyor göründüğünü ifade eder (Köse, 2012; Tekin, 2010).

4. Ölçüt dayanaklı geçerlik: Aynı özelliği ölçme amacıyla geliştirilmiş ve geçerliği önceden belirlenmiş olan bir ölçme aracı ile geçerliği belirlenmeye çalışılan aracinın her ikisinin de aynı gruba uygulanması sonucunda elde edilen puanlar arasındaki korelasyonun hesaplanmasına dayalıdır. Bu geçerlik türü iki şekilde incelenir (Tekin, 2010; Turgut, 1984):

4.1. Uygunluk geçerliği: Uyum geçerliği olarak da bilinen bu geçerlik türü, test puanları ile testin verildiği zamanda yapılan veya bulunan kriter ölçütler arasındaki ilişkiye atfedilir (Tekindal, 2012). Bu ölçütler, bağımsız değiş̧ken ile aynı zamanda veya yakın zamanda uygulanan ve aynı niceliği ölçen bir ölçme aracından elde edilen puanlar olabileceği gibi öğretmenlerin bildirmiş olduğu görüşler, vermiş olduğu notlar veya geçmiş yıllara ait ders başarı ölçüleri de olabilir (Baykul, 2010).

4.2. Yordama geçerliği: Yordama bir tahmindir fakat her tahmini bir yordama olarak nitelendirmek doğru değildir. Yapılan tahminlerin yordama olarak nitelendirebilmesi için geleceğe ile ilgili olması ve aynı zamanda istatistiksel teknikler aracılığı ile yapılması gerekir. Bu söylenenlerden hareketle yordama, bazı istatistiksel teknikleri kullanarak bilinen veriler 1şı̆̆ında bilinmeyenler hakkında geleceğe dönük tahminler yapma işidir (Tekin, 2010). Crocker ve Algina (1986) yordama geçerliğini, ölçüt puanların bireylerin ölçülen özellikler açısından gelecekteki performansını yansıtması durumunda, testin ölçüt puanları yordama gücü olarak tanımlamışlardır.

Ölçüt olarak kullanılan puanlar, geçerliği belirlenmeye çalışılan ölçme aracından alınan puanlardan sonra elde edilmişse, bu puanlar arasında yapılan korelâsyona dayalı geçerliğe yordama geçerliği adı verilir (Baykul, 2010). Test puanları, testin uygulandığı bireylerin ölçülen özellik açısından ilerideki performansını yordamak için yani ölçülen özellik bakımından bireyin gelecekteki performansının ne olacağını belirlemek için kullanılacaksa ve ölçüt olarak kabul edilen puanlar test uygulandıktan sonra elde ediliyorsa yordama geçerliği kullanılır (Erkuş, 2003).

$\mathrm{Bu}$ araştırmada öğrencilerin 6. ve 7. sınıf matematik, Türkçe, din kültürü ve ahlak bilgisi, fen bilimleri, sosyal bilgiler ve İngilizce derslerine ait başarı ölçülerinin Temel Eğitimden Ortaöğretime Geçiş (TEOG) sınavı alt testi ham puanlarını yordama düzeyi incelenmektedir. Öğrencilerin TEOG sınavı puanlarını yordadığı düşünülen matematik, Türkçe, din kültürü ve ahlak bilgisi, fen bilimleri, sosyal bilgiler ve İngilizce derslerine ait başarı ölçüleri yordayıcı değişken olarak ele alınırken 2014 yılı TEOG sınavı alt testi ham puanları da ölçüt değişken olarak ele alınmıştır. 


\section{Araştırmanın Modeli}

\section{Yöntem}

$\mathrm{Bu}$ araştırma da TEOG sınavına giren öğrencilerin TEOG sınavı alt testi ham puanları ile ortaokuldaki ilgili derslere ait ders başarı ölçüleri arasındaki ilişki belirlenmeye çalışılmıştır. İki ya da ikiden fazla değişken arasındaki birlikte değişimin varlığını ve/veya derecesini belirlemeyi amaçladığından bu araştırma ilişkisel tarama modelindedir (Karasar, 2005).

\section{Çalışma Grubu}

Bu araştırma Bolu ili Mudurnu ilçesinde bulunan 8 ortaokuldan 2014-2015 eğitim öğretim yılı TEOG sınavına her iki dönemde de girmiş 2218 . sinıf öğrencisi üzerinden yürütülmüştür. Bu gruptan 2014-2015 eğitim öğretim y1lında TEOG sınavina girmiş olan 21 öğrencinin geçmiş dönemlere ait ders notlarına okul değiştirmeleri nedeni ile ulaşılamadığı için bu öğrenciler analizlere dahil edilmemiştir. Bu nedenle araştırmaya 200 öğrenciye ait veriler üzeriden devam edilmiştir.

\section{Verilerin Toplanması}

Araştırmada kullanılmak amacıyla aynı öğrenciye ait 6. ve 7. sınıf yazılı sınav, ders etkinliklerine katılım ve performans görevi puanları okulların sınıf geçme defterlerinden; aynı öğrencilerin TEOG sınavı alt testi ham puanları okulların e-okul sistemi veri tabanından elde edilmiştir.

\section{Verilerin Analizi}

$\mathrm{Bu}$ araştırmanın probleminin çözümü için öğrencilerin 6. ve 7. sınıf matematik, Türkçe, din kültürü ve ahlak bilgisi, fen bilimleri, sosyal bilgiler ve İngilizce dersi yazılı sınav, ders etkinliklerine katılım ve performans görevi puanları bağımsız (yordayıc1) değişken; TEOG sınavı matematik, Türkçe, din kültürü ve ahlak bilgisi, fen bilimleri, sosyal bilgiler ve İngilizce alt testi ham puanları ayrı ayrı bağımlı (ölçüt) değişken olarak ele alınmıştır. Bağımlı değişken ile bağımsız değişkenler arasındaki ilişki çoklu regresyon analizi ile incelenmiştir.

\section{Bulgular}

Çoklu regresyon yönteminin uygulanması için veri setinin bazı varsayımları yerine getirmesi gerekmektedir. Bu araştırmada analizlere başlamadan önce bağımsız değişkenler arasında çoklu bağlantı olup olmadığı, otokorelasyonun olup olmadığı, bağımlı değişkenler ile bağımsız değişkenler arasındaki ilişkinin doğrusal olup olmadığı ve puanların çok değişkenli normal dağılım gösterip göstermediği test edilmiştir.

Yordayıcı değişkenler arasında çoklu bağlantı olup olmadığını anlamak için değişkenler arasındaki korelasyon incelenir. Değişkenler arasında 0,80 üzerinde bir korelasyon çoklu bağlantının olabileceğini, 0,90 üzerinde bir korelasyon ise ciddi bir çoklu bağlantı sorununun olabileceğini gösterir. Ayrıca varyans şişme faktörü (VIF) değerinin 10'nun altında, tolerans değerinin (TD) 0,20'nin üstünde ve durum indeksi (CI) değerinin 30'dan düşük çıkması çoklu bağlantı probleminin olmadı̆̆ını göstermektedir (Büyüköztürk, 2010). Otokorelasyon olup olmadığını ortaya 
çıkarmada Durbin Watson $(D W)$ değerine bakılır. $D W$ değerinin 2 civarında olması otokorelasyonun olmadığını göstermektedir (Kalayc1, 2014).

Ayrıca yordayıcı değişkenler ile yordanan değişken arasındaki ilişkinin doğrusallığı ve puanların normal dağılıp dağılmadığını belirlemek için analizler sonucunda oluşturulan grafikler incelenmiştir.
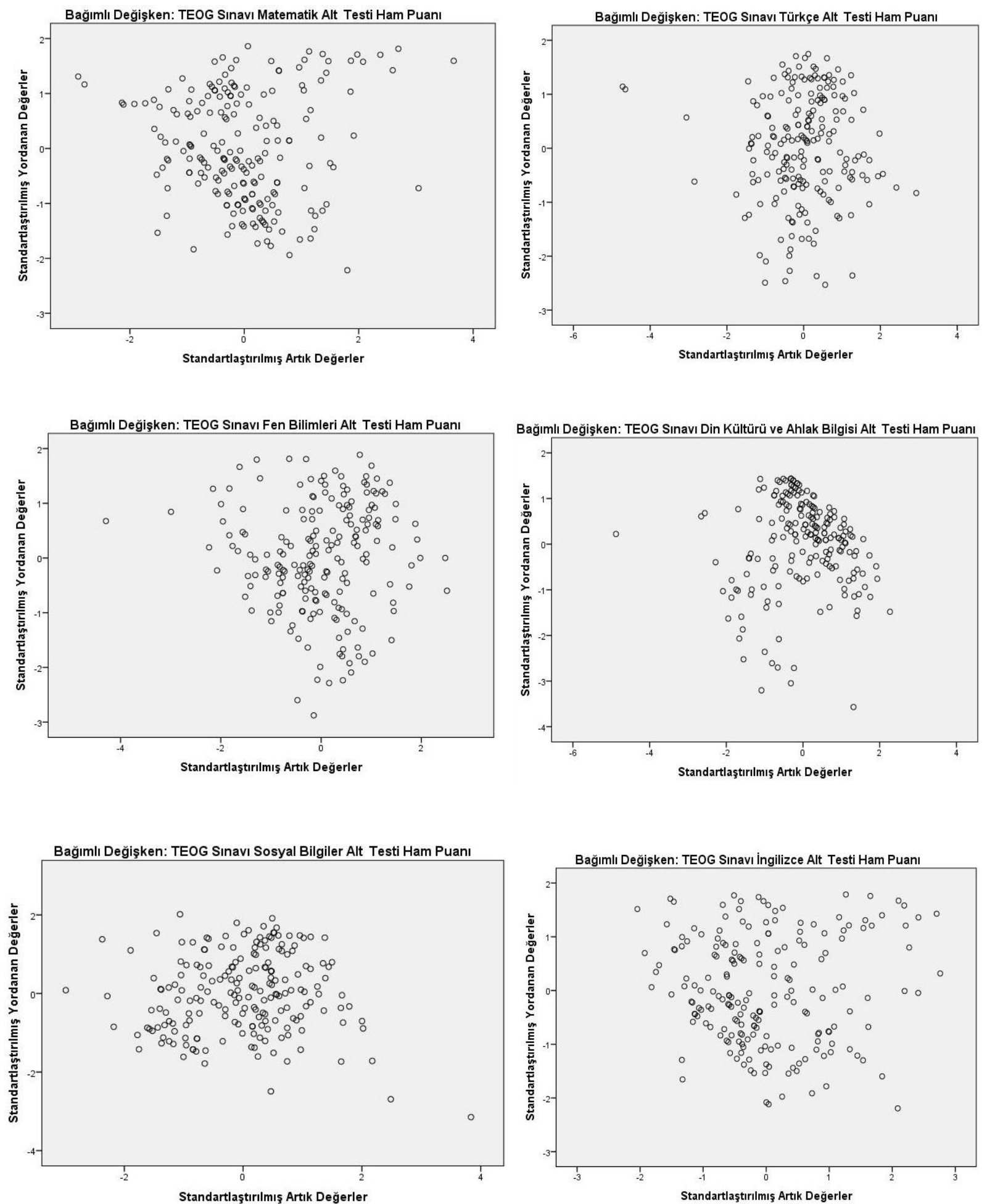

Şekil 1. Standartlaştırılmış Artık Değerler İle Standartlaştırılmış Yordanan Değerler İçin Oluşturulan Saçılma Diyagramları 
Doğrusallık varsayımı için oluşturulan grafikler incelendiğinde standartlaştırılmış artık değerler ile standartlaştırılmış yordanan değerleri gösteren saçılma diyagramının doğrusal bir ilişkiyi gösterdiği ve noktaların bir eksen etrafında toplandığı görülmüştür.

TEOG Matematik Alt Test Puanları Histogram ve Normal Dağılım Eğrileri
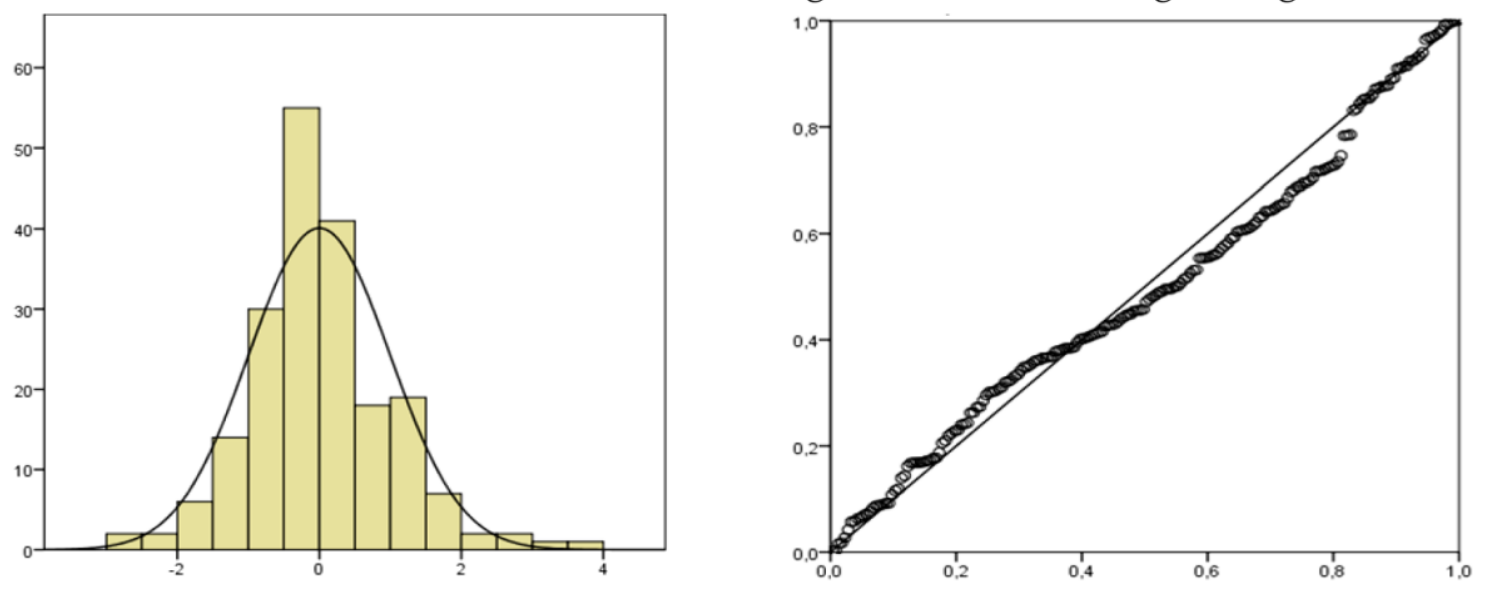

TEOG Türkçe Alt Test Puanları Histogram ve Normal Dağılım Eğrileri
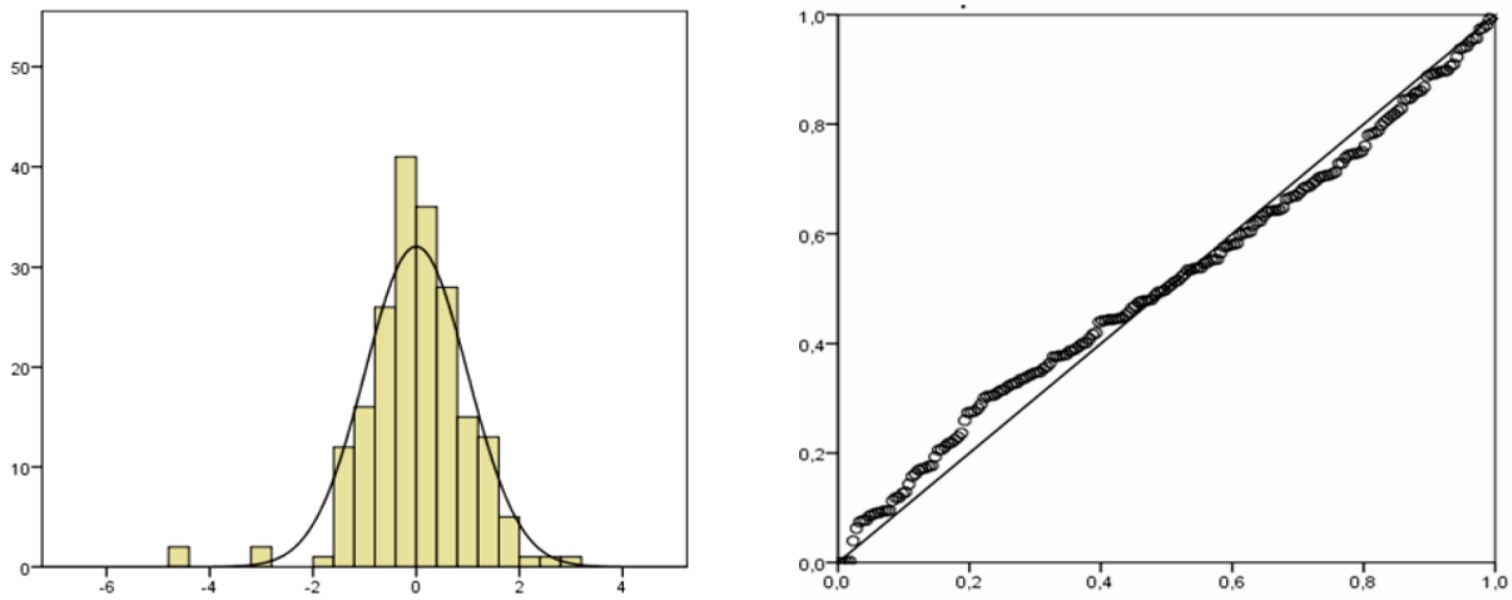

TEOG Din Kültürü ve Ahlak Bilgisi Alt Test Puanları Histogram ve Normal Dağılım Eğrileri
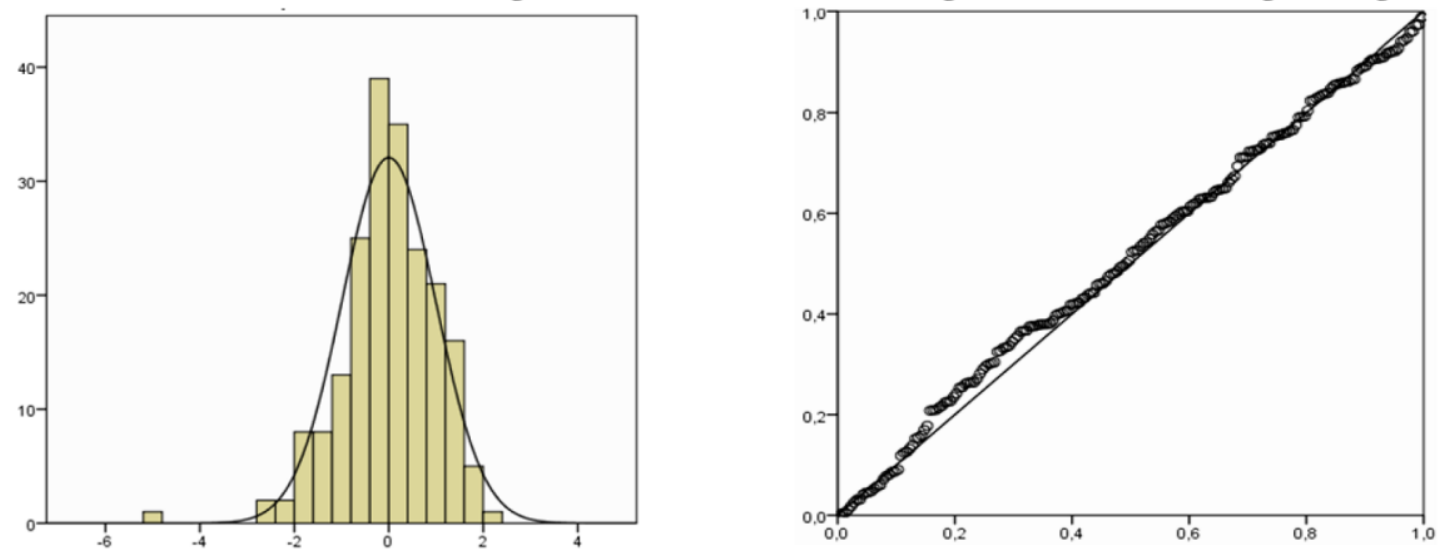

Şekil 2. Standartlaştırılmış Yordanan Değerler İçin Oluşturulan Histogram ve Normal Dağılım Eğrileri 
TEOG Fen Bilimleri Alt Test Puanları Histogram ve Normal
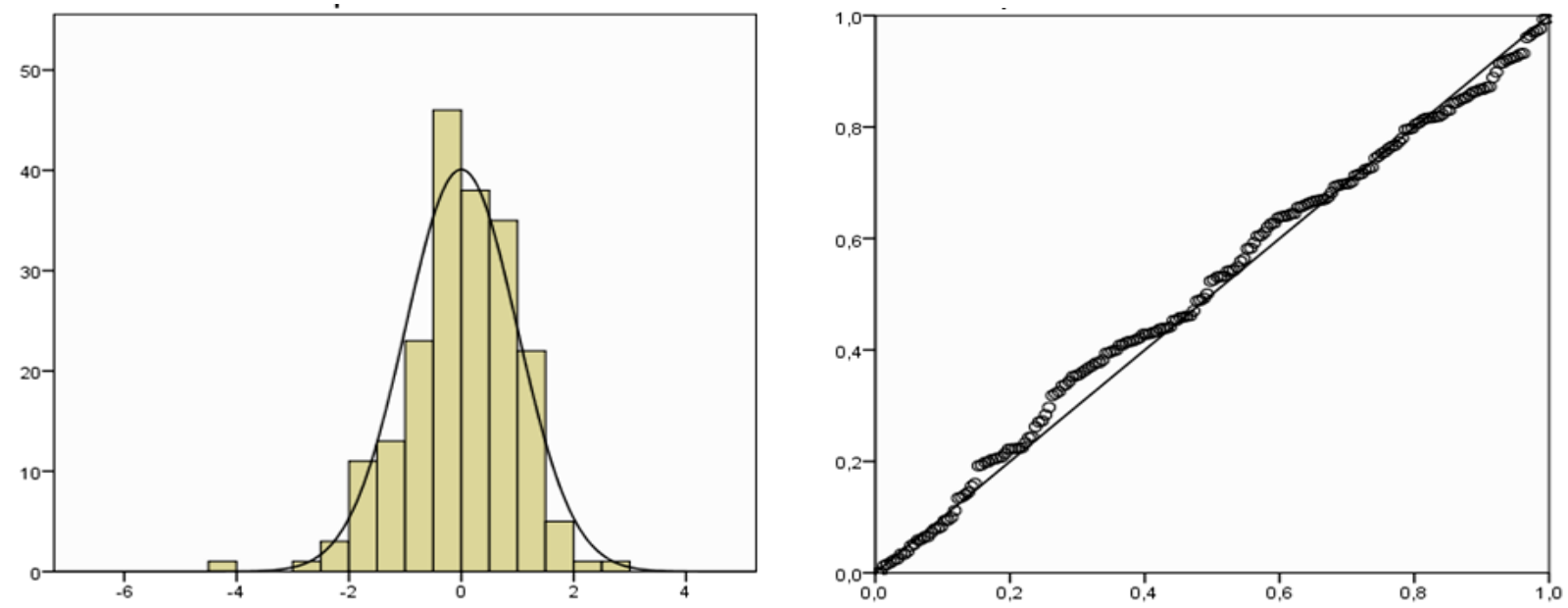

Dağılım Ĕ̆rileri

TEOG Sosyal Bilgiler Alt Test Puanları Histogram ve Normal Dağılım Eğrileri
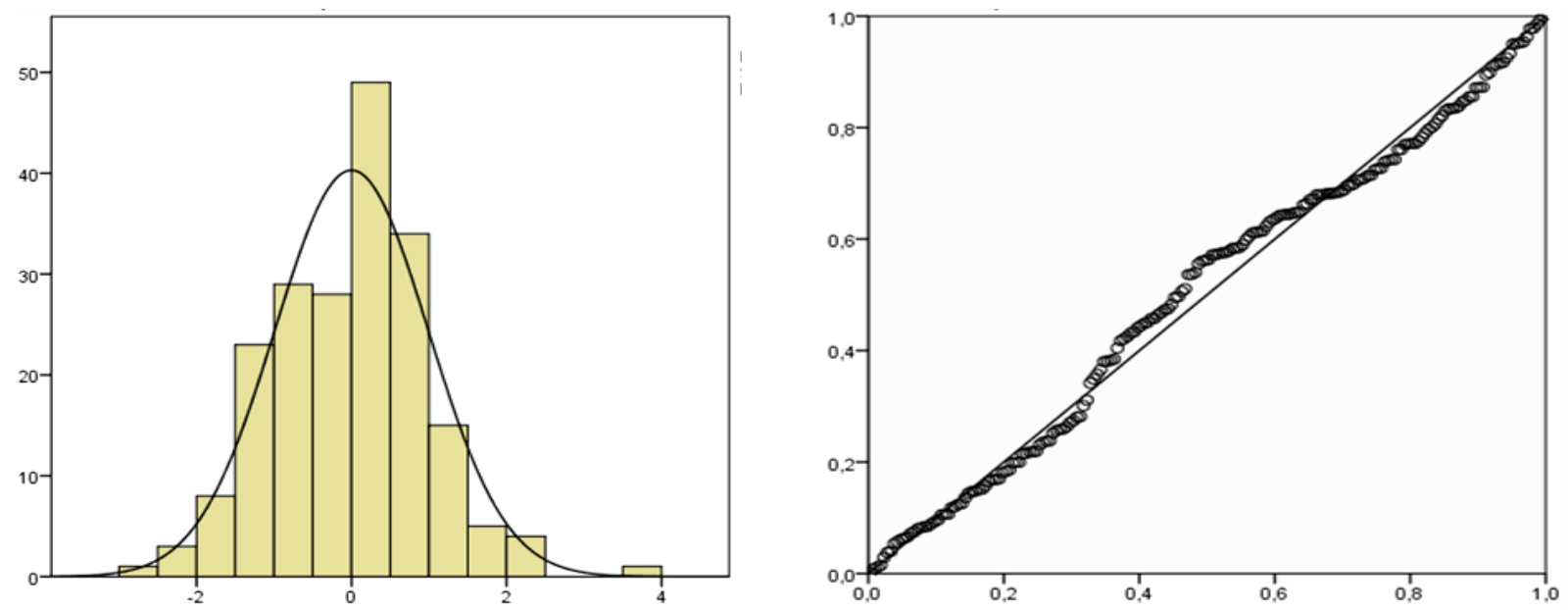

TEOG İngilizce Alt Test Puanları Histogram ve Normal Dağılım Eğrileri
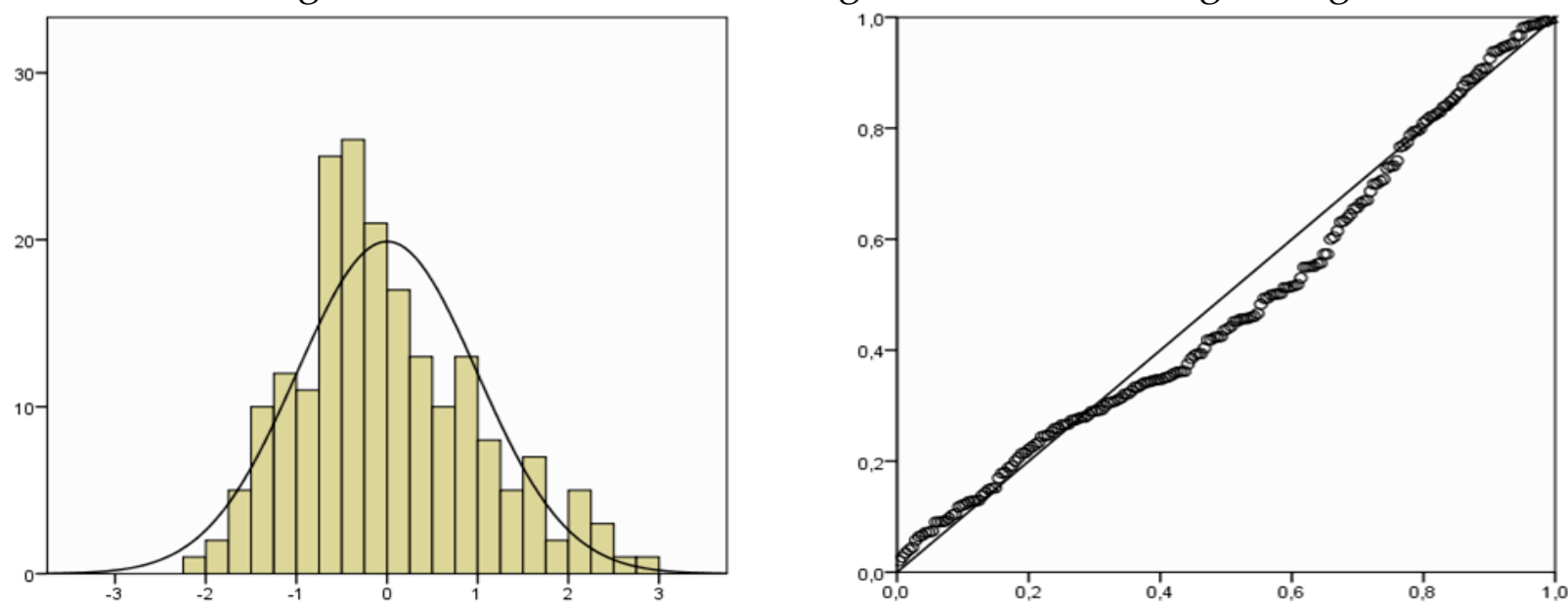

Şekil 3. Standartlaştırılmış Yordanan Değerler İçin Oluşturulan Histogram ve Normal Dağılım Eğrileri 
Normallik varsayımları için oluşturulan grafikler incelendiğinde ise standartlaştırılmış yordanan değerleri gösteren normal dağılım ve histogram eğrilerinin normale yakın bir dağılım gösterdikleri görülmüştür.

Bağımsız değişkenler arasında çoklu bağlantı problemi olup olmadığını belirlemek için değişkenler arasındaki ilişkilere bakılmıştır. Değişkenler arasındaki ilişkiyi belirlemek için Pearson Momentler Çarpımı Korelasyon Katsayısı kullanılmış ve çözümlemelerden elde edilen bilgiler Tablo 1'de verilmiştir.

Tablo 1'de verilen matematik dersi bağımsız değişkenleri arasındaki korelasyon incelendiğinde en yüksek manidar korelasyonun 6. sınıf yazılı sınav puanı ile 6. sınıf ders etkinliklerine katılım puanı arasında $(r=0,88)$, en düşük manidar korelasyonun 7. sınıf yazılı sınav puanı ile 7. sınıf performans görevi puanı arasında $(r=0,37)$ olduğu; Türkçe dersi bağımsız değişkenleri arasındaki korelasyon incelendiğinde en yüksek manidar korelasyonun 7. sınıf yazılı sınav puanı ile 7. sınıf ders etkinliklerine katılım puanı arasında $(r=0,87)$, en düşük manidar korelasyonun 7. sınıf performans görevi puanı ile 6. sınıf ders etkinliklerine katılım puanı arasında $(r=0,61)$ olduğu; din kültürü ve ahlak bilgisi dersi bağımsız değişkenleri arasındaki korelasyon incelendiğinde en yüksek manidar korelasyonun 7. sınıf yazılı sınav puanı ile 7. sınıf ders etkinliklerine katılım puanı arasında $(r=0,88)$, en düşük manidar korelasyonun 7. sınıf performans görevi puanı ile 6. sinıf ders etkinliklerine katılım puanı arasında $(r=0,34)$ olduğu; fen bilimleri dersi bağımsız değişkenleri arasındaki korelasyon incelendiğinde en yüksek manidar korelasyonun 6. sinıf yazılı sınav puanı ile 6. sınıf yazılı sınav puanı arasında $(r=0,89)$, en düşük manidar korelasyonun 7. sinıf ders etkinliklerine katılım puanı ile 6. sinıf performans görevi puanı arasında $(r=0,39)$ olduğu; sosyal bilgiler dersi bağımsız değişkenleri arasındaki korelasyon incelendiğinde en yüksek manidar korelasyonun 6. sinıf yazılı sınav puanı ile 6. sınıf ders etkinliklerine katılım puanı arasında $(r=0,83)$, en düşük manidar korelasyonun 7. sinıf performans görevi puanı ile 6. sinıf ders etkinliklerine katılım puanı arasında $(r=0,56)$ olduğu; İngilizce dersi bağımsız değişkenleri arasındaki korelasyon incelendiğinde en yüksek manidar korelasyonun 6. sinıf yazılı sınav puanı ile 6. sınıf ders etkinliklerine katılım puanı arasında $(r=0,89)$, en düşük manidar korelasyonun 7. sınıf performans görevi puanı ile 6. sınıf performans görevi puanı arasında $(r=0,63)$ olduğu görülmektedir.

Çoklu bağlantı durumunun kontrolü için verilen bağımsız değişkenler arasındaki korelasyon katsayıları incelendiğinde bazı değişkenler arasındaki korelasyonun 0,80 'den büyük olduğu görülmüştür. Bu nedenle çoklu bağlantı durumunun incelenmesinde korelasyon ile beraber CI (durum indeksi) değerlerinin koşullara uygunluğuna bakılmıştır. CI değerleri Tablo 2'de verilmiştir. 
Tablo 1

Değişkenler Arasındaki Korelasyonlar

\begin{tabular}{|c|c|c|c|c|c|c|c|c|c|}
\hline & & Değişkenler & 1 & 2 & 3 & 4 & 5 & 6 & 7 \\
\hline \multirow{6}{*}{ 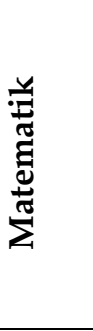 } & 1 & 6. Sınıf Ders Etkinliklerine Katılım & - & & & & & & \\
\hline & 2 & 6. Sınıf Performans Görevi & $0.76^{*}$ & - & & & & & \\
\hline & 3 & 6. Sinif Yazılı Sinav & $0.88^{*}$ & $0.73^{*}$ & - & & & & \\
\hline & 4 & 7. Sınıf Ders Etkinliklerine Katılım & $0,83^{*}$ & $0.70^{*}$ & $0.77^{*}$ & - & & & \\
\hline & 5 & 7. Sınıf Performans Görevi & $0.42^{*}$ & $0.41^{*}$ & $0.38^{*}$ & $0.42^{*}$ & - & & \\
\hline & 6 & 7. Sınıf Yazılı Sınav & $0.82^{*}$ & $0.69^{*}$ & $0.85^{*}$ & $0.84^{*}$ & $0.37^{*}$ & - & \\
\hline \multirow{6}{*}{ 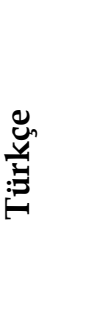 } & 1 & 6. Sınıf Ders Etkinliklerine Katılım & - & & & & & & \\
\hline & 2 & 6. Sinıf Performans Görevi & $0.86^{*}$ & - & & & & & \\
\hline & 3 & 6. Sinif Yazılı Sinav & $0.86^{*}$ & $0.84^{*}$ & - & & & & \\
\hline & 4 & 7. Sınıf Ders Etkinliklerine Katılım & $0.74^{*}$ & $0.73^{*}$ & $0.79^{*}$ & - & & & \\
\hline & 5 & 7. Sınıf Performans Görevi & $0.61^{*}$ & $0.66^{*}$ & $0.67^{*}$ & $0.79^{*}$ & - & & \\
\hline & 6 & 7. Sinif Yazılı Sinav & $0.71^{*}$ & $0.70^{*}$ & $0.75^{*}$ & $0.87^{*}$ & $0.81^{*}$ & - & \\
\hline \multirow{6}{*}{ 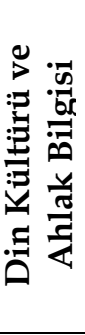 } & 1 & 6. Sınıf Ders Etkinliklerine Katılım & - & & & & & & \\
\hline & 2 & 6. Sınıf Performans Görevi & $0.49^{*}$ & - & & & & & \\
\hline & & 6. Sinif Yazılı Sinav & $0.57^{*}$ & $0.77^{*}$ & - & & & & \\
\hline & 4 & 7. Sınıf Ders Etkinliklerine Katılım & $0.36^{*}$ & $0.59^{*}$ & $0.74^{*}$ & - & & & \\
\hline & 5 & 7. Sınıf Performans Görevi & $0.34^{*}$ & $0.63^{*}$ & $0.70^{*}$ & $0.86^{*}$ & - & & \\
\hline & 6 & 7. Sinıf Yazılı Sinav & $0.47^{*}$ & $0.64^{*}$ & $0.82^{*}$ & $0.88^{*}$ & $0.87^{*}$ & - & \\
\hline \multirow{7}{*}{ 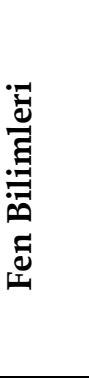 } & 1 & 6. Sınıf Ders Etkinliklerine Katılım & - & & & & & & \\
\hline & 2 & 6. Sinıf Performans Görevi & $0.75^{*}$ & - & & & & & \\
\hline & 3 & 6. Sinif Yazılı Sinav & $0.89^{*}$ & $0.74^{*}$ & - & & & & \\
\hline & 4 & 7. Sınıf Ders Etkinliklerine Katılım & $0.42^{*}$ & $0.39^{*}$ & $0.43^{*}$ & - & & & \\
\hline & 5 & 7. Sinıf Performans Görevi & $0.59^{*}$ & $0.72^{*}$ & $0.58^{*}$ & $0.40^{*}$ & - & & \\
\hline & 6 & 7. Sinif Yazılı Sinav & $0.82^{*}$ & $0.74^{*}$ & $0.88^{*}$ & $0.51^{*}$ & $0.71^{*}$ & - & \\
\hline & 7 & 8. Sinif TEOG Alt Test & $0.67^{*}$ & $0.57^{*}$ & $0.73^{*}$ & $0.38^{*}$ & $0.55^{*}$ & $0.74^{*}$ & - \\
\hline \multirow{6}{*}{ 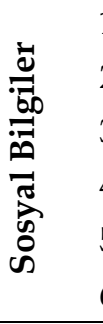 } & 1 & 6. Sınıf Ders Etkinliklerine Katılım & - & & & & & & \\
\hline & 2 & 6. Sınıf Performans Görevi & $0.61^{*}$ & - & & & & & \\
\hline & 3 & 6. Sinif Yazılı Sinav & $0.83^{*}$ & $0.73^{*}$ & - & & & & \\
\hline & 4 & 7. Sınıf Ders Etkinliklerine Katılım & $0.71^{*}$ & $0.64^{*}$ & $0.72^{*}$ & - & & & \\
\hline & 5 & 7. Sinıf Performans Görevi & $0.56^{*}$ & $0.68^{*}$ & $0.62^{*}$ & $0.78^{*}$ & - & & \\
\hline & 6 & 7. Sinif Yazılı Sinav & $0.66^{*}$ & $0.63^{*}$ & $0.74^{*}$ & $0.82^{*}$ & $0.79^{*}$ & - & \\
\hline \multirow{6}{*}{ 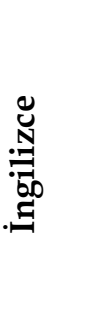 } & 1 & 6. Sınıf Ders Etkinliklerine Katılım & - & & & & & & \\
\hline & 2 & 6. Sınıf Performans Görevi & $0.74^{*}$ & - & & & & & \\
\hline & 3 & 6. Sinıf Yazılı Sinav & $0.89^{*}$ & $0.70^{*}$ & - & & & & \\
\hline & 4 & 7. Sınıf Ders Etkinliklerine Katılım & $0.83^{*}$ & $0.65^{*}$ & $0.83^{*}$ & - & & & \\
\hline & 5 & 7. Sınıf Performans Görevi & $0.71^{*}$ & $0.63^{*}$ & $0.73^{*}$ & $0.78^{*}$ & - & & \\
\hline & 6 & 7. Sinif Yazılı Sinav & $0.83^{*}$ & $0.64^{*}$ & $0.86^{*}$ & $0.88^{*}$ & $0.78^{*}$ & - & \\
\hline
\end{tabular}

${ }^{*} p<0.01$ 
Tablo 2

Değisskenlere İlişkin Condition Index Değerleri

\begin{tabular}{llc}
\hline & Değişkenler & Condition Index (CI) \\
\hline Matematik & Sabit & 1.00 \\
& 6. Sınıf Yazılı Sınav & 8.59 \\
& 7. Sınıf Ders Etkinliklerine Katılım & 18.69 \\
\hline Türkçe & Sabit & 1.00 \\
& 7. Sınıf Yazılı Sınav & 8.68 \\
& 7. Sınıf Ders Etkinliklerine Katılım & 20.15 \\
\hline Din Kültürü ve Ahlak Bilgisi & Sabit & 1.00 \\
& 7. Sınıf Yazılı Sınav & 10.58 \\
& 6. Sınıf Yazılı Sınav & 19.92 \\
\hline Fen Bilimleri & Sabit & 1.00 \\
& 7. Sınıf Yazılı Sınav & 8.39 \\
& 6. Sınıf Yazılı Sınav & 20.71 \\
\hline Sosyal Bilgiler & Sabit & 1.00 \\
& 7. Sinıf Yazılı Sınav & 11.80 \\
& 7. Sınıf Performans Görevi & 15.03 \\
& 6. Sinıf Yazılı Sınav & 19.33 \\
& 6. Sınıf Performans Görevi & 27.36 \\
\hline İngilizce & Sabit & 1.00 \\
& 7. Sınıf Ders Etkinliklerine Katılım & 10.78 \\
6. Sınıf Yazılı Sınav & 17.69 \\
& 6. Sınıf Performans Görevi & 22.82 \\
\hline
\end{tabular}

Analizlere ilişkin varsayımların test edilmesine yönelik $C I$ değerleri Tablo 2'de görülmektedir. Tablo 2'de verilen CI değerlerinin koşulları sağladı̆̆ı belirlenmiştir. Değişkenler arasında çoklu bağlantı probleminin olup olmadığını belirlemek için CI değerlerinin yanında VIF (varyans şişme faktörü) ve TD (tolerans değeri) değerleri incelenmiş sonuçlar Tablo 3 'te verilmiştir. Tablo 3 'te çoklu bağlantı problemini belirlemek için verilen VIF ve TD değerlerinin yanında otokorelasyon olup olmadığını ortaya çıkarmak için $D W$ (durbin watson) değeri verilmiştir.

Varsayımların test edilmesine ilişkin VIF, TD ve $D W$ değerleri Tablo 3 'te görülmektedir. Tablo 3 te verilen VIF ve $T D$ değerlerinin istenilen ölçütleri karşıladiğ1 belirlenmiştir. Son olarak incelenen VIF ve TD değerleri ile beraber değişkenler arasında çoklu bağlantı probleminin olmadığı belirlenmiştir. Diğer yandan otokorelasyon olup olmadığını belirlemek için verilen DW değerlerinin istenilen koşulları sağladığı görülmektedir. Regresyon analizi yapılabilmesi için gerekli varsayımların test edildikten sonra çoklu regresyon analizinin adımsal tekniği kullanılmış ve analiz sonuçları tablolar halinde verilmiştir. 
Tablo 3

Değişkenlere İlişkin VIF, TD ve DW Değerleri

\begin{tabular}{llccc}
\hline & Değişkenler & VIF & TD & DW \\
\hline Matematik & 6. Sınıf Yazılı Sınav & 3.32 & 0.30 & \multirow{2}{*}{1.42} \\
& 7. Sınıf Ders Etkinliklerine Katılım & 3.32 & 0.30 & \\
\hline Türkçe & 7. Sınıf Yazılı Sınav & 4.05 & 0.24 & \multirow{2}{*}{1.91} \\
& 7. Sınıf Ders Etkinliklerine Katılım & 4.05 & 0.24 & \\
\hline Din Kültürü ve & 7. Sınıf Yazılı Sınav & 3.14 & 0.31 & \multirow{2}{*}{2.06} \\
Ahlak Bilgisi & 6. Sınıf Yazılı Sınav & 3.14 & 0.31 & \\
\hline Fen Bilimleri & 7. Sınıf Yazılı Sınav & 4.95 & 0.20 & \multirow{2}{*}{1.58} \\
& 6. Sınıf Yazılı Sınav & 4.95 & 0.20 & \\
\hline Sosyal Bilgiler & 7. Sınıf Yazılı Sınav & 3.87 & 0.25 & \\
& 7. Sınıf Performans Görevi & 3.35 & 0.29 & \multirow{2}{*}{1.58} \\
& 6. Sınıf Yazılı Sınav & 3.12 & 0.32 & \\
& 6. Sınıf Performans Görevi & 2.73 & 0.36 & \\
\hline İngilizce & 7. Sınıf Ders Etkinliklerine Katılım & 3.35 & 0.29 & \multirow{2}{*}{1.31} \\
& 6. Sinıf Yazılı Sınav & 3.74 & 0.26 & \\
& 6. Sınıf Performans Görevi & 2.04 & 0.48 & \\
\hline
\end{tabular}

Tablo 4

TEOG Matematik Alt Testinin Yordanmasına İlişkin Aşamalı Çoklu Regresyon Analizi Sonuçları

\begin{tabular}{|c|c|c|c|c|c|c|}
\hline Model & Yordayıcı & $B$ & $S H_{B}$ & $\beta$ & $R^{2}$ & Kismi Korelasyon \\
\hline \multirow[t]{2}{*}{1} & $6 Y S$ & 0.53 & 0.05 & $0.59^{* *}$ & $0.351^{* *}$ & 0.59 \\
\hline & Sabit & 1.40 & 3.25 & & & \\
\hline \multirow[t]{3}{*}{2} & $6 Y S$ & 0.32 & 0.09 & $0.36^{* *}$ & $0.023^{* *}$ & 0.24 \\
\hline & 7DEK & 0.28 & 0.10 & $0.28^{* *}$ & & 0.19 \\
\hline & Sabit & -6.37 & 4.13 & & & \\
\hline$R=0.61$ & $R^{2}=$ & & & & & \\
\hline
\end{tabular}

Tablo 4'te verilen çoklu regresyon analizi sonucuna göre öğrencilerin 6 . ve 7 . sınıf matematik dersi başarı notları bağımsız değişkenleri birlikte bağımlı değişken TEOG matematik alt testi ham puanlarını anlamlı bir biçimde $(R=, 611 ; p<0,01)$ yordamaktadır. Tablo 4'e göre analizin iki aşamada tamamlandığı ve TEOG matematik başarısına ilişkin varyansa katkıları bakımından iki değişkenin önemli yordayıcılar olduğu görülmektedir. Analize birinci aşamada TEOG sınavı matematik alt testi değişkeninde en fazla varyansı açıklayan 6. sınıf yazılı sınav değişkeni girmiştir. Bu değişken TEOG sınavındaki matematik başarısının \%35'ini açıklamaktadır. Analize ikinci aşamada açıklanan varyansa anlamlı en fazla katkı getiren 7. sınıf ders etkinliklerine katılım değişkeni girmiştir. Bu değişken TEOG sınavındaki matematik başarısına ilişkin açıklanan varyansa \%2,3'lük bir katkı 
sağlamaktadır. Bu iki değişken birlikte TEOG sınavındaki matematik alt testi başarısındaki toplam varyansın \%37,4'ünü açıklamaktadır.

Tablo 5

TEOG Türkçe Alt Testinin Yordanmasına İlişkin Aşamal Çoklu Regresyon Analizi Sonuçları

\begin{tabular}{llccccc}
\hline Model & Yorday1c1 & $\mathrm{B}$ & $\mathrm{SH}_{\mathrm{B}}$ & $\beta$ & $\mathrm{R}^{2}$ & Kismi Korelasyon \\
\hline 1 & 7YS & 1.02 & 0.05 & $0.80^{\text {** }}$ & $0.641^{* *}$ & 0.80 \\
& Sabit & -5.72 & 3.57 & & & \\
& & & & & & 0.43 \\
2 & 7YS & 0.71 & 0.11 & $0.56^{* *}$ & $0.019^{* *}$ & 0.23 \\
& 7DEK & 0.36 & 0.11 & $0.27^{* *}$ & & \\
& Sabit & -14.15 & 4.33 & & & \\
\hline $\mathrm{R}=0.812$ & \multicolumn{2}{c}{$\mathrm{R}^{2}=0.660$} & & & & \\
$\mathrm{~F}_{(2.197)}=191.112$ & $\mathrm{p}=0.00$ & & & \\
\hline
\end{tabular}

Tablo 5'te verilen çoklu regresyon analizi sonucuna göre öğrencilerin 7. sinıf Türkçe dersi başarı notları bağımsız değişkenleri birlikte bağımlı değişken TEOG Türkçe alt testi ham puanlarını anlamlı bir biçimde $(R=0,812 ; p<0,01)$ yordamaktadır. Tablo 5'e göre analizin iki aşamada tamamlandığı ve TEOG Türkçe başarısına ilişkin varyansa katkıları bakımından iki değişkenin önemli yordayıcılar olduğu görülmektedir. Analize birinci aşamada TEOG sınavı Türkçe alt testi değişkeninde en fazla varyansı açıklayan 7. sınıf yazılı sınav değişkeni girmiştir. Bu değişken TEOG sınavındaki Türkçe başarısının \%64,1'ini açıklamaktadır. Analize ikinci aşamada açıklanan varyansa anlamlı en fazla katkı getiren 7 . sınıf ders etkinliklerine katılım değişkeni girmiştir. Bu değişken TEOG sınavındaki Türkçe başarısına ilişkin açıklanan varyansa \%1,9'luk bir katkı sağlamaktadır. Bu iki değişken birlikte TEOG sınavındaki Türkçe alt testi başarısındaki toplam varyansın \%66'sını açıklamaktadır.

Tablo 6

TEOG Din Kültürü ve Ahlak Bilgisi Alt Testinin Yordanmasına İlişkin Aşamalı Çoklu Regresyon Analizi Sonuçları

\begin{tabular}{llccccc}
\hline Model & Yordayıc1 & $\mathrm{B}$ & $\mathrm{SH}_{\mathrm{B}}$ & $\beta$ & $\mathrm{R}^{2}$ & Kismi Korelasyon \\
\hline 1 & 7YS & 1.18 & 0.06 & $0.81^{* *}$ & $0.659^{* *}$ & 0.81 \\
& Sabit & -13.64 & 4.68 & & & \\
& & & & & & 0.44 \\
2 & $7 \mathrm{YS}$ & 0.67 & 0.10 & $0.46^{* *}$ & $0.057^{* *}$ & 0.41 \\
& GYS & 0.63 & 0.10 & $0.42^{* *}$ & & \\
& Sabit & -20.31 & 4.41 & & & \\
\hline$R=0.846$ & $\mathrm{R}^{2}=0.716$ & & & & \\
$\mathrm{~F}_{(2.197)=284.384}$ & $\mathrm{p}=0.00$ & & & & & \\
\hline
\end{tabular}

Tablo 6'da verilen çoklu regresyon analizi sonucuna göre öğrencilerin 6. ve 7. sınıf din kültürü ve ahlak bilgisi dersi başarı notları bağımsız değişkenleri birlikte bağımlı değişken TEOG din kültürü ve ahlak bilgisi alt testi ham puanlarını anlamlı bir biçimde $(R=0,846 ; p<0,01)$ yordamaktadır. Tablo 6'ya göre analizin iki aşamada 
tamamlandığı ve TEOG din kültürü ve ahlak bilgisi başarısına ilişkin varyansa katkıları bakımından iki değişkenin önemli yordayıcılar olduğu görülmektedir. Analize birinci aşamada TEOG sınavı din kültürü ve ahlak bilgisi alt testi değişkeninde en fazla varyansı açıklayan 7. sınıf yazılı sınav değişkeni girmiştir. Bu değişken TEOG sınavındaki din kültürü ve ahlak bilgisi başarısının \%65,9'unu açıklamaktadır. Analize ikinci aşamada açıklanan varyansa anlamlı en fazla katkı getiren 6. sınıf yazılı sınav değişkeni girmiştir. Bu değişken TEOG sınavındaki din kültürü ve ahlak bilgisi başarısına ilişkin açıklanan varyansa \%5,7'lik bir katkı sağlamaktadır. Bu iki değişken birlikte TEOG sınavındaki din kültürü ve ahlak bilgisi alt testi başarısındaki toplam varyansın \%71,6'sını açıklamaktadır.

Tablo 7

TEOG Sosyal Bilgiler Alt Testinin Yordanmasına İlişkin Aşamalı Çoklu Regresyon Analizi Sonuçları

\begin{tabular}{|c|c|c|c|c|c|c|}
\hline Model & Yordayıc1 & $B$ & $\mathrm{SH}_{B}$ & $\beta$ & $R^{2}$ & Kismi Korelasyon \\
\hline \multirow[t]{2}{*}{1} & $7 Y S$ & 0.83 & 0.69 & $0.66^{* *}$ & $0.432^{* *}$ & 0.65 \\
\hline & Sabit & -5.43 & 4.58 & & & \\
\hline \multirow[t]{3}{*}{2} & $7 Y S$ & 1.17 & 0.11 & $0.93^{* *}$ & $0.042^{* *}$ & 0.61 \\
\hline & $7 P G$ & -0.40 & 0.10 & $-0.34^{* *}$ & & -0.27 \\
\hline & Sabit & 13.44 & 4.86 & & & \\
\hline \multirow[t]{4}{*}{3} & $7 Y S$ & 0.90 & 0.12 & $0.71^{\text {** }}$ & $0.045^{* *}$ & 0.46 \\
\hline & 7PG & -0.42 & 0.09 & $-0.36^{* *}$ & & -0.30 \\
\hline & $6 Y S$ & 0.38 & 0.89 & $0.39^{* *}$ & & 0.29 \\
\hline & Sabit & 8.98 & 4.78 & & & \\
\hline \multirow[t]{5}{*}{4} & 7YS & 0.86 & 0.12 & $0.67^{\star *}$ & $0.16^{* *}$ & 0.45 \\
\hline & $7 P G$ & -0.30 & 0.10 & $-0.26^{* *}$ & & -0.21 \\
\hline & $6 \mathrm{YS}$ & 0.51 & 0.10 & $0.44^{* *}$ & & 0.34 \\
\hline & $6 \mathrm{PG}$ & -0.28 & 0.11 & $-0.21^{* *}$ & & -0.18 \\
\hline & Sabit & 15.97 & 5.44 & & & \\
\hline $\begin{array}{l}R=0.731 \\
F_{(4.195)}=\end{array}$ & & & & & & \\
\hline
\end{tabular}

Tablo 7'de verilen çoklu regresyon analizi sonucuna göre öğrencilerin 6. ve 7 . sınıf sosyal bilgiler dersi başarı notları bağımsız değişkenleri birlikte bağımlı değişken TEOG sosyal bilgiler alt testi ham puanlarını anlamlı bir biçimde $(R=0,731$; $p<0,01)$ yordamaktadır. Tablo 7'ye göre analizin dört aşamada tamamlandığ1 ve TEOG sosyal bilgiler başarısına ilişkin varyansa katkıları bakımından dört değişkenin önemli yordayıcılar olduğu görülmektedir. Analize birinci aşamada TEOG sınavı sosyal bilgiler alt testi değişkeninde en fazla varyansı açılayan 7. sınıf yazılı sınav değişkeni girmiştir. Bu değişken TEOG sınavındaki sosyal bilgiler başarısının \%43,2'sini açıklamaktadır. Sonraki aşamalarda analize sırasıyla TEOG sınavındaki sosyal bilgiler başarısına ilişkin açıklanan varyansa \%4,2'lik bir katkı getiren 7. sınıf performans görevi değişkeni, \%4,5'lik bir katkı getiren 6 . sınıf yazılı sınav değişkeni, \%1,6'lık katkı getiren 6 . sınıf performans görevi değişkeni girmiştir. 
Bu dört değişken birlikte TEOG sınavındaki sosyal bilgiler alt testi başarısındaki toplam varyansın \%53,4'ünü açıklamaktadır.

Tablo 8

TEOG İngilizce Alt Testinin Yordanmasına İlişkin Aşamalı Çoklu Regresyon Analizi Sonuçları

\begin{tabular}{|c|c|c|c|c|c|c|}
\hline Model & Yordayıc1 & $\mathrm{B}$ & $\mathrm{SH}_{\mathrm{B}}$ & $\beta$ & $\mathrm{R}^{2}$ & Kısmi Korelasyon \\
\hline \multirow[t]{2}{*}{1} & 7DEK & 0.86 & 0.07 & $0.66^{* *}$ & $0.442^{* *}$ & 0.66 \\
\hline & Sabit & -23.41 & 5.35 & & & \\
\hline \multirow[t]{3}{*}{2} & 7DEK & 0.59 & 0.12 & $0.93^{* *}$ & $0.032^{* *}$ & 0.29 \\
\hline & $6 Y S$ & 0.36 & 0.11 & $-0.34^{* *}$ & & 0.24 \\
\hline & Sabit & -21.43 & 5.24 & & & \\
\hline \multirow[t]{4}{*}{3} & 7DEK & 0.60 & 0.12 & $0.71^{* *}$ & $0.038^{* *}$ & 0.34 \\
\hline & $6 Y S$ & 0.52 & 0.11 & $-0.36^{* *}$ & & 0.32 \\
\hline & $6 \mathrm{PG}$ & -0.38 & 0.10 & $0.39^{* *}$ & & -0.27 \\
\hline & Sabit & -9.17 & 5.97 & & & \\
\hline \multicolumn{2}{|c|}{$\mathrm{R}=0.716$} & & & & & \\
\hline
\end{tabular}

Tablo 8'de verilen çoklu regresyon analizi sonucuna göre öğrencilerin 6 . ve 7 . sınıf İngilizce dersi başarı notları bağımsız değişkenleri birlikte bağımlı değişken TEOG İngilizce alt testi ham puanlarını anlamlı bir biçimde $(R=0,716 ; p<0,01)$ yordamaktadır. Tablo 8'e göre analizin üç aşamada tamamlandığı ve TEOG İngilizce başarısına ilişkin varyansa katkıları bakımından üç değişkenin önemli yordayıcılar olduğu görülmektedir. Analize birinci aşamada TEOG sinavı İngilizce alt testi değişkeninde en fazla varyansı açıklayan 7. sınıf ders etkinliklerine katılım değişkeni girmiştir. $\mathrm{Bu}$ değişken TEOG sınavındaki İngilizce başarısının \%44,2'sini açıklamaktadır. Sonraki aşamalarda analize sırasıyla TEOG sınavındaki İngilizce başarısına ilişkin açıklanan varyansa \%3,2'lik bir katkı getiren 6. sınıf yazılı sınav değişkeni, \%3,8'lik bir katkı getiren 6. sınıf performans görevi değişkeni girmiştir. Bu üç değişken birlikte TEOG sınavındaki İngilizce alt testi başarısındaki toplam varyansın \%51,2'sini açıklamaktadır.

\section{Sonuç, Tartışma ve Öneriler}

Araştırma ile öğrencilerin ortaokul 6. ve 7. sınıf matematik, Türkçe, din kültürü ve ahlak bilgisi, fen bilimleri, sosyal bilgiler ve İngilizce derslerine ait başarı ölçülerinin TEOG sınavı alt testi ham puanlarını yordama düzeyi incelenmiştir. Araştırmanın sonuçlarına göre TEOG sınavı matematik alt testi başarısını en yüksek yordayan değişkenin matematik dersi başarı ölçülerinden yazılı sınav değişkeni olduğu; matematik alt testinin varyansını 6 . sınıf ders başarı ölçülerinin 7. sınıf ders başarı ölçülerinden daha yüksek düzeyde açıkladığı; matematik dersi başarı ölçülerinden performans görevi puanı değişkenin TEOG sınavı matematik başarısını açıklamada yetersiz kaldığ1 görülmektedir. Verim (2006) yaptığ1 araştırmasında, 6. sınıf matematik dersleri başarı ölçülerinin OKS matematik alt testinden alınan ham puanları yordamadığı; 7. sınıf Türkçe dersleri başarı ölçülerinin OKS Türkçe alt 
testinden alınan ham puanları yordamadığı; 8. sınıf sosyal bilgiler dersleri başarı ölçülerinin OKS sosyal bilgiler alt testinden alınan ham puanları yordamadığı sonuçlarına ulaşmıştır. Verim'in (2006) bulgularının bu araştırmanın birinci alt probleminin bulgularını destekler nitelikte olmadığı söylenebilir.

TEOG sınavı Türkçe alt testi başarısını en yüksek yordayan değişkenin Türkçe dersi başarı ölçülerinden yazılı sınav değişkeni olduğu; Türkçe alt testinin varyansını 7. sınıf başarı ölçüleri anlamlı bir şekilde açıklarken 6. sınıf başarı ölçülerinin Türkçe alt testinin varyansını açıklamada yetersiz kaldığı; ayrıca Türkçe dersi başarı ölçülerinden performans görevi puanı değişkenin TEOG sınavı Türkçe başarısını açıklamada yetersiz kaldığı görülmektedir. Parlak ve Tatlıdil (2013) yaptıkları araştırmada, Türkçe ve fen bilimleri dersleri başarı ölçülerinin SBS alt testlerindeki başarıyı açıklamada en iyi yordayıcı değişken olduğu sonucuna ulaşmışlardır. Parlak ve Tatlıdil'in (2013) elde etmiş olduğu bulguları bu araştırmanın ikinci alt probleminin bulgularını destekler niteliktedir. Ancak Verim'in (2006) bulgularının bu araştırmanın ikinci alt probleminin bulgularını destekler nitelikte olmadığ1 söylenebilir.

TEOG sınavı din kültürü ve ahlak bilgisi alt testi başarısını en yüksek düzeyde yordayan değişkenlerin din kültürü ve ahlak bilgisi dersi başarı ölçülerinden yazılı sınav değişkeleri olduğu; din kültürü ve ahlak bilgisi alt testinin varyansını 7. sınıf başarı ölçülerinin 6. sınıf başarı ölçülerine göre daha fazla açıkladığı; ayrıca din kültürü ve ahlak bilgisi dersi başarı ölçülerinden ders etkinliklerine katılım ve performans görevi puanı değişkenin TEOG sınavı din kültürü ve ahlak bilgisi başarısını açıklamada yetersiz kaldığı görülmektedir.

TEOG sınavı fen bilimleri alt testi başarısını en yüksek düzeyde yordayan değişkenin fen bilimleri dersi başarı ölçülerinden yazılı sınav değişkeleri olduğu; fen bilimleri alt testinin varyansını 7. sınıf başarı ölçülerinin 6. sınıf başarı ölçülerine göre daha fazla açıkladığı; ayrıca fen bilimleri dersi başarı ölçülerinden ders etkinliklerine katılım ve performans görevi puanı değişkenin TEOG sınavı fen bilimleri başarısını açıklamada yetersiz kaldığı görülmektedir. Güzeller (2012) yaptığ1 araştırmasında, SBS fen bilimleri alt testini en yüksek yordayan değişkenin okul başarı puanlarından yazılı sınav değişkeni olduğu; performans görevi değişkeninin SBS fen bilimleri alt testi başarısının anlamlı yordayıcısı olmadığı sonuçlarına ulaşmıştır. Güzeller'in (2012) bulguları bu araştırmanın dördüncü alt probleminin bulgularını destekler niteliktedir. Yine Parlak ve Tatlıdil'in (2013) elde etmiş olduğu bulgular bu araştırmanın dördüncü alt probleminin bulgularını destekler niteliktedir.

TEOG sınavı sosyal bilgiler alt testi başarısını en yüksek yordayan değişkenin sosyal bilgiler dersi başarı ölçülerinden yazılı sınav değişkeleri olduğu; sosyal bilgiler alt testinin varyansını 7. sınıf başarı ölçülerinin 6. sınıf başarı ölçülerine göre daha fazla açıkladığı; sosyal bilgiler dersi başarı ölçülerinden ders etkinliklerine katılım değişkenin TEOG sınavı sosyal bilgiler başarısını açıklamada yetersiz kaldığı; ayrıca sosyal bilgiler dersi başarı ölçülerinden performans görevi puanı değişkenin matematik, Türkçe, din kültürü ve ahlak bilgisi ve fen bilimleri derslerinin aksine hem 7. sinıf hem de 6. sınıf düzeyinde TEOG sınavı sosyal bilgiler başarısını açıkladığı görülmektedir. 
TEOG sınavı İngilizce alt testi başarısını en yüksek yordayan değişkenin İngilizce dersi başarı ölçülerinden ders etkinliklerine katılım değişkeni olduğu; İngilizce alt testinin varyansını 7. sınıf başarı ölçülerinin 6. sınıf başarı ölçülerine göre daha fazla açıkladı̆̆ı; ayrıca İngilizce dersi başarı ölçülerinden performans görevi puanı değişkenin matematik, Türkçe, din kültürü ve ahlak bilgisi ve fen bilimleri derslerinin aksine 6. sınıf düzeyinde TEOG İngilizce başarısını açıkladığı görülmektedir. Baş (2013) yaptığı araştırmasında, SBS İngilizce alt testi başarısını en yüksek düzeyde yordayan değişkenin İngilizce dersi akademik ortalamalarından yazılı sınav değişkeni olduğu sonucuna ulaşmıştır. Bununla birlikte öğrencilerin SBS İngilizce alt testi başarısını ikinci sırada yordayan değişkenin performans görevi puanı, üçüncü sırada yordayan değişkenin ise ders etkinliklerine katılım puanı olduğu sonuçlarına ulaşmıştır. Yordayıcı değişkenlerin İngilizce alt testi başarı puanı üzerindeki önem sırası farklılık gösterse de Baş'ın (2013) elde etmiş olduğu bulgular bu araştırmanın altıncı alt probleminin bulgularını destekler niteliktedir.

MEB (2014b) ilköğretimin temel amacını, öğrencilerin yeteneklerini ve ilgilerini geliştirip öğrencileri bir üst öğrenime ve hayata hazırlamak; onlara değerlerimizi, temel bilgi ve becerileri kazandırmak şeklinde ifade etmektedir. Öğrencilerin temel bilgi ve becerileri kazanması, ilgi ve yeteneklerini geliştirerek üst öğrenime hazırlanması okul öğrenmeleri ile mümkündür. Bu öğrenmeler öğrencilerin bir sonraki eğitim kademesindeki başarısını olumlu yönde etkileyecektir. Yapılan araştırmalar da bireyin önceden elde etmiş olduğu birikimlerinin sonraki öğrenmeleri olumlu yönde etkilediğini ortaya çıkarmaktadır (Baş, 2013; Güzeller, 2005; Güzeller, 2012; Kan, 2004; Önen, 2003). Bu bağlamda düşünüldüğünde okul başarı puanları ile ortaöğretime geçiş için gerçekleştirilen TEOG sınavı puanları arasında ilişki olması beklenir.

Araştırma kapsamında incelenen 6. ve 7. sınıf düzeyindeki bağımsız değişkenlere bakıldığında ortaokullarda 8. sınıf düzeyinde gerçekleştirilen TEOG sınavı alt testi başarısını en yüksek yordayan değişkenin yazılı sınav puan ortalamaları olduğu görülmektedir. Bu durumun bir eğitim öğretim yılı içerisinde okullarda gerçekleştirilen yazılı sınav sayısının fazla (İngilizce ve din kültürü ve ahlak bilgisi dersi için dönemde 2 adet diğer dersler için dönemde 3 adet) olmasından kaynaklanmış olabileceği düşünülmektedir. Ayrıca öğrencilerin başarısını belirlemek için kullanılan soru türlerinin de problem çözme, yaratıcı düşünme, eleştirel düşünme, sorgulama ve araştırma gibi üst düzey zihinsel becerilerini geliştirmesi bir etken olabilir.

Diğer taraftan bağımsız değişkenlerden ders etkinliklerine katılım puanlarının TEOG başarısının yordamada yetersiz kaldığı görülmektedir. Bu durumun ders etkinliklerine katılım puanlarının verilmesinde öğretmenlerin objektif puanlama yapmamış olmasından kaynaklanmış olabileceği düşünülmektedir. Ortaöğretime geçiş uygulaması kapsamında gerçekleştirilen bu sınav sisteminin amacı öğretim programını etkili bir biçimde uygulamak ve öğrencinin ulaşması istenen kazanımları objektif olarak izlemek ve sonuçları değerlendirmek olarak ifade edilmektedir (MEB, 2014a). Bu bağlamda ders etkinliklerine katılım değişkeninin TEOG sınavı alt testi ham puanlarını yordamada yetersiz kalması sınav sisteminin amacını tam anlamıla gerçekleştirmesine engel teşkil etmektedir. Bu anlamda öğretmenlerin tamamlayıcı 
ölçme ve değerlendirme teknikleri ile ilgili eksiklerinin olduğu ve öğretmenlerin bu konuda hizmet içi eğitim faaliyetlerine ihtiyaç duydukları söylenebilir.

Araştırmanın bağımsız değişkenlerden performans görevi puanlarının da TEOG başarısının yordamada yetersiz kaldığı görülmektedir. Performans görevi puanlarının önemli yordayıcı olmaması verilen performans görevlerinin niteliği ile ilgili olabileceği gibi öğretmenlerin değerlendirme ölçütlerini net bir şekilde ortaya koymaması ve böylece puanlamanın doğru yapılmayışından kaynaklanmış olabileceği düşünülmektedir. Diğer bir sorunun ise öğrencilerin performans görevi çalışmalarında başkalarından yardım almış olabilmeleri sebebiyle bu puanların öğrencilerin başarısını yansıtmıyor olabileceği düşünülmektedir. Bu sonuç her ne kadar eğitim sistemimizden performans görevinin kaldırılmasını destekler nitelikte olsa da performans görevinin kaldırılması, yeni sınav sisteminin amaçlarına ters düşmektedir. Bakanlık yeni uygulamanın temel niteliğini "öğrenci başarısını anlık bir performansa dayalı olarak değil, geniş bir zaman dilimine yayarak belirlemek" şeklinde ifade etmektedir (MEB, 2014a). Yeni sistemin amaçları göz önüne alındığında "öğrencilere gerçek yaşamda karşılaşabilecekleri problemler sunan ve üst düzey düşünme becerilerinin gelişmesini sağlayan performans görevini" (Doğan, Karakaya ve Kutlu; 2008) kaldırmaktan ziyade eksiklerin belirlenip daha işlevsel hale getirilmesi için çalışmaların yapılmasının daha isabetli bir karar olacağı düşünülmektedir.

$\mathrm{Bu}$ araştırmanın alt problemlerinin çözümünde çalışma grubu olarak Bolu ili Mudurnu ilçesinde TEOG sınavına giren öğrenciler alınmıştır. Yeni yapılacak araştırmalardan elde edilecek bulguların evrene genellenebilmesi için evreni temsil edecek bir grup üzerinde çalışma yapılabilir. Bu araştırma 2014 yılından itibaren uygulanmaya başlayan TEOG sınavının ikinci yılına ait veriler üzerinden yürütülmüştür. Yine bu tür araştırmalardan elde edilen bulguların genellenebilirliğini artırmak için bu sınav sistemlerinin değişik yıllardaki sonuçları üzerinden aynı çalışma yapılabilir. 2018 yılında tek oturumda uygulanacak yeni sınav uygulamasına geçildiğinde yordama geçerliği incelenerek sonuçlar karsılaştırılabilir.

\section{Kaynakça}

Abacı, Ç. Ç. (2015). Merkezi sistem ortak sınavlarının farklı değişkenler açısından irdelenmesi (Yayımlanmamış Yüksek Lisans Tezi). Gazi Üniversitesi Eğitim Bilimleri Enstitüsü, Ankara.

Anastasi, A. (1988). Psychological testing. New York: Mac Millan Publications.

Arıc1, H. (1997). İstatistik yöntemler ve uygulamalar. Ankara: Meteksan Basımevi.

Baykul, Y. (1992). Ĕ̆itim sisteminde değerlendirme. Hacettepe Üniversitesi Eğitim Fakültesi Dergisi, 7, 85-94.

Baykul, Y. (2010). Eğitimde ve psikolojide ölçme: Klasik test teorisi ve uygulaması. Ankara: Pegem Akademi.

Balc1, A. (2009). Sosyal bilimlerde araştırma yöntem, teknik ve ilkeler. Ankara: Pegem Akademi.

Baş, G. (2013). İlköğretim İngilizce dersi akademik ortalamaları ile seviye belirleme sınav Ingilizce alt testi sonuçları arasındaki ilişkinin yapısal eşitlik modeli ile 
incelenmesi. Ondokuz Mayıs Üniversitesi Eğitim Fakültesi Dergisi, 32(2), 5576.

Büyüköztürk, Ş. (2014). Sosyal bilimler için veri analizi el kitabı (19. Baskı). Ankara: Pegem Akademi.

Crocker, L. and Algina, J. (1986). Introduction to classical and modern test theory. New York: Holt, Reinhart and Wilson.

Demirel, Ö. (2004). Eğitimde program geliştirme. Ankara: Pegem Yayıncılık.

Deniz, Z. (2003). İlköğretim akademik başarı ölçüleri ile orta öğretim kurumları ögrenci seçme ve yerleştirme sinav puanları arasındaki uygunluk geçerliği çalışması (Yayımlanmamış Yüksek Lisans Tezi). Ankara Üniversitesi Eğitim Bilimleri Enstitüsü, Ankara.

Erkuş, A. (2003). Psikometri üzerine yazılar. Ankara: Türk Psikologlar Derneği.

Ertürk, S. (1972). Eğitimde program geliştirme. Ankara: Yelkentepe Yayınları.

Fidan, N. (1985). Okulda ögrrenme ve öğretme (3. Bask1). Ankara: Pegem Akademi.

Güler, Z. (2010). İlköğretim öğrencilerinin SBS puanları ile ders başarıları, bilimsel süreç becerileri ve mantıksal düşünme yetenekleri arasındaki ilişki (Yayımlanmamış Yüksek Lisans Tezi). Abant İzzet Baysal Üniversitesi Sosyal Bilimler Enstitüsü, Bolu.

Gülleroğlu, D. (2005). Üniversite öğrencilerinin akademik başarllarının yordanmasına ilişkin karşılaştırmalı bir araştırma ( Yayımlanmamış Doktora Tezi). Ankara

Üniversitesi Eğitim Bilimleri Enstitüsü, Ankara.

Güzeller, C.O. (2005). Ortaöğretim kurumları iğrenci seçme ve yerleştirme sınavınn geçerliği (Yayınlanmamış Doktora Tezi). Hacettepe Üniversitesi Sosyal Bilimler Enstitüsü, Ankara.

Güzeller, C. O. (2012). İlköğretim fen ve teknoloji dersi akademik ortalamalar ile seviye belirleme sınav fen bilimleri alt testi puanları arasındaki ilişki. Kuram ve Uygulamada Eğitim Bilimleri Dergisi, 12(1), 201-214.

Kalaycı, Ş. (Ed.). (2005). SPSS uygulamalı çok değişkenli istatistik teknikleri. Ankara: Asil Yayın Dağıtım.

Kan, A. (2005). ÖSS'ye kaynaklı eden alan derslerindeki başarı ile ÖSS'den elde edilen puanlar arasındaki ilişkinin incelenmesi. Eğitim ve Bilim Dergisi, 30(137), 38-44.

Kan, A. (2009). Ölçme aracında bulunması gereken nitelikler. H. Atılgan (ed.), Eğitimde Ölçme ve Değerlendirme İçinde (23-80). Ankara: Anı Yayıncılık.

Karakaya, İ. (2002). Orta öğretim kurumları öğrenci seçme ve yerleştirme sınavının yordama geçerliğine ilişkin bir araştırma (Yayımlanmamış Yüksek Lisans Tezi). Ankara Üniversitesi Eğitim Bilimleri Enstitüsü, Ankara.

Karakaya, İ. (2007). Yükseköğretime öğrenci seçme sınavının (ÖSS) yordama geçerliğ $i$ (Yayımlanmamış Doktora Tezi). Ankara Üniversitesi Eğitim Bilimleri Enstitüsü, Ankara.

Kelecioğlu, H. (2003). Ortaöğretim başarı puanlarının üniversiteye girişte iki aşamah sinavda uygulanan ÖYS, ÖSS ve tek aşamalı sinavda uygulanan ÖSS ile ilişkileri. Hacettepe Üniversitesi Eğitim Fakültesi Dergisi, (24), 70-78.

Kelecioğlu, H. (2004). Üniversiteye girişte iki aşamalı sınavda uygulanmış olan öğrenci seçme sinavı puanları ile ögrrenci yerleştirme sınavı puanları arasındaki ilişkiler. Eğitim ve Bilim Dergisi, 29(133), 60-70. 
Koç, N. (1987). Öğrenci gelişiminin değerlendirilmesi-okul test programları. Ankara Üniversitesi Eğitim Bilimleri Fakültesi Dergisi, 19(1-2), 281-294.

Köse, İ.A. (2012). Ölçmede geçerlilik. N. Çıkrıkç1-Demirtaşlı, (Ed.), Eğitimde Ölçme ve Değerlendirme İçinde (71-90). Ankara: Elhan Yayınları.

Milli Eğitim Bakanlığ1 [MEB], (2013). 2014 yılı bütçe sunuşu TBMM genel kurulu. Ankara: MEB Strateji Geliştirme Başkanlığı. http://sgb.meb.gov.tr/meb_iys_dosyalar/2013_12/25103155_butce_sunusu _2014.pdf adresinden erişilmiştir.

MEB, (2014a). Temel eğitimden ortaöğretime geçiş sunumu. Ankara. (http://oges.meb.gov.tr/docs2104/sunum.pdf 20 Şubat 2015'te erişildi).

MEB, (2014b). Milli Eğitim Bakanlığı okul öncesi eğitim ve ilköğretim kurumları yönetmeliği. http://www.resmigazete.gov.tr/eskiler/2014/07/201407264.htm adresinden erişilmiştir.

Önen, E. (2003). Ortaöğretim kurumları öğrenci seçme ve yerleştirme sınav başarısı ve lise 1. sınfftaki akademik başarıya ilişkin bir yordama geçerliği çalışması: fen lisesi örneği (Yayımlanmamış Yüksek Lisans Tezi). Ankara Üniversitesi Eğitim

Bilimler Enstitüsü, Ankara.

Örnek, E. (2002). Hacettepe üniversitesi sosyal bilimler enstitüsüne bă̆lı yüksek lisans programındaki lisans üstü eğitimi giriş smavn puanları ile akademik başarıları arasındaki ilişkiler (Yayımlanmamış Yüksek Lisans Tezi). Hacettepe Üniversitesi Sosyal Bilimler Enstitüsü, Ankara.

Özdamar, K. (2013). Paket programlar ile istatistiksel veri analizi (9. Bask1). Eskişehir: Nisan Kitapevi.

Özdemir, H. (2014). İlköğretim ve ortaöğretim başarı ölçülerinin yükseköğretime geçiş sınav puanların yordama gücü (Yüksek Lisans Tezi). Abant İzzet Baysal

Üniversitesi Eğitim Bilimleri Enstitüsü, Bolu.

Parlak, B. ve Tatlıdil, H. (2013). 8. sını öğrencilerinin okul başarılarn ile test puanları arasındaki ilişkinin çok boyutlu incelenmesi. Dumlupınar Üniversitesi Sosyal Bilimler Dergisi, 24, 335-350.

Sayın, A. (2010). Öğrenci seçme ve yerleştirme sınavının üniversite başarı not ortalaması ve ortaöğretim başan puanı ile ilişkisi (Yayımlanmamış Yüksek Lisans Tezi). Hacettepe Üniversitesi Sosyal Bilimler Enstitüsü, Ankara.

Sevindik, H. (2009). Akademik başarı puanlarının seviye belirleme sınavı (SBS) 2008 puanları ile ilişkisi (Yayımlanmamış Yüksek Lisans Tezi). Hacettepe Üniversitesi Sosyal Bilimler Enstitüsü, Ankara.

Sönmez, V. (2012). Program geliştirmede öğretmen el kitabı. Ankara: Anı Yayıncılık.

Tekin, H. (2010). Ĕ̆itimde ölçme ve değerlendirme. Ankara: Yarg1 Yayınevi.

Tekindal, S. (2012). Okullarda ölçme ve değerlendirme yöntemleri. Ankara: Nobel Yayıncilik.

Tokat, E. ve Demirtaşlı, N.Ç. (2004). Lisans üstü ĕgitimi giriş sınavı (LES) ve diğer kabul ölçülerinin yordama geçerliliğine ilişkin bir çalışma. Eğitim Bilimleri ve Uygulama Dergisi, 3(5), 35-55.

Turgut, M. F. (1984). Eğitimde ölçme ve değerlendirme metotları. Ankara: Saydam Matbaacilik.

Varış, F. (1978). Eğitimde program geliştirme: Teori ve teknikleri. Ankara Üniversitesi Eğitim Fakültesi Yayınları. 
Verim, A. (2006). İlköğretim düzeyindeki bazı başarı ölçülerinin ortaöğretim kurumları öğrenci seçme sınavını yordama gücü ( Yayımlanmamış Yüksek Lisans Tezi). Hacettepe Üniversitesi Sosyal Bilimler Enstitüsü, Ankara.

Yakar, L. (2011). İlköğretim ikinci kademe öğrencilerinin SBS puanlar ve akademik başarı puanları değişimlerinin izlenmesi ve SBS puanlarının kestirilmesi (Yayımlanmamış Yüksek Lisans Tezi). Abant İzzet Baysal Üniversitesi Eğitim Bilimleri Enstitüsü, Bolu.

\section{Summary}

\section{Introduction}

There are several definitions of education by different researchers. Fidan (1986) defined it as raising individuals in the light of predetermined goals; Demirel (2004) defined education as the process of changing individuals' behavior via acculturation in their lives in the light of well-defined programs and planning. When we analyze these definitions we can easily see that there is a need for pre-determined goals and there will be change in human behavior though their educational lives.

Nowadays, education is considered as a system which results in change in human behavior. Similar to other systems there will be inputs, process, controlling and outputs of education system. Measurement and evaluation is the controlling system of education as other systems (Baykul, 2010; Sönmez, 2012).

Turgut (1984) defined measurement as expressing quality of something with numbers or symbols referring to results of observations. He defined evaluation as comparing measurement results to a measurement tool to make a decision. Accurate results depend on validity and reliability of measurement tools (Baykul, 2010).

This study investigated the relationship between secondary school entrance exam scores (TEOG) and students' academic achievement during their elementary school years. Main goal of the study was to examine how well grade 6 and 7 mathematics, Turkish, education of religion and ethics, science, social sciences and English scores (independent variables) predict TEOG exam scores (dependent variable) in from year 2014. Grade 6 and 7 mathematics, Turkish, ethics, science, social sciences and English written exam scores, participation levels in classroom activities and performance grades were independent variables. Mathematics, Turkish, education of religion and ethics, science, social sciences and English scores in TEOG exams were dependent variables of the study.

\section{Method}

This study investigates the relationship between students' secondary school entrance exam scores and related subject area scores. Comparative study method was used to investigate this relationship (Karasar, 2005).

Participants were from eight different secondary schools in Bolu/Turkey. Data of the study included 221 of grade 8 students' 2014-2015 secondary school entrance exam scores. Additionally, their grade 6 and grade 7 exam scores, participation and performance task scores were other data sources of the study. Data were gathered from Turkish e-school online system. The relationship between 
dependent and independent variables were analyzed using multiple regression analysis.

\section{Findings}

Grade 6 and 7 written exam scores were better predictor of TEOG exam scores in mathematics, Turkish, education of religion and ethics, science, social sciences when compared to other independent variables. On the other hand, participation levels to classroom activities were better predictor of TEOG English exam scores when compared to other independent variables. Additionally, while performance task scores are a predictor of TEOG scores in social sciences and English, it is not a predictor of mathematics, Turkish, education of religion and ethics, and sciences.

\section{Discussion}

Grade 6 and 7 written exam scores were better predictor of TEOG exam scores when compared to other independent variables. This might be because of the number of written exams (there are two written exams in each semester for English and education of religion and ethics and three for other subject areas). Additionally, the types of questions used in these exams might be developing students' higher order thinking skills: problem solving, creative and critical thinking, and questioning and research skills.

On the other hand, participation levels to classroom activities were not good predictor of TEOG exam scores when compared to other independent variables. This might be because of being not objective enough while assessing students' participation levels in classroom activities. Teachers might need support about measurement and evaluation strategies which can be done via in-service trainings.

Performance task scores were not good predictor of TEOG exam scores. This might be because of unclear expectations of these tasks and their quality. This might put reliability of these measurements at risk. Another reason might be students' cheating issues while performing these tasks.

This study might be done with larger sample sizes to get better results. Another suggestion is doing the same study using data from different years.

\section{Authors' Biodata / Yazar Bilgileri}

Gürkan KARAKOÇ Bolu İl Milli Eğitim Müdürlüğü'nde öğretmen olarak görev yapmaktadir.

Gürkan Karakoç works as a teacher in Bolu Provincial Directorate of National Education.

İbrahim Alper KÖSE Abant İzzet Baysal Üniversitesi Eğitim Fakültesi Eğitim Bilimleri Bölümü'nde doçent doktor olarak görev yapmaktadır.

İbrahim Alper Köse is an associate professor at Abant İzzet Baysal University, Faculty of Education Department of Educational Sciences. 